STUDIA PRAWNO-EKONOMICZNE, T. CXIII, 2019

PL ISSN 0081-6841; e-ISSN 2450-8179 $\quad$ s. 53-68

https://doi.org/10.26485/SPE/2019/113/3

\title{
Monika GŁADOCH*
}

iD https://orcid.org/0000-0001-9814-5627

\section{OCENA WYBRANYCH REGULACJI PROJEKTU KODEKSU PRACY KOMISJI KODYFIKACYJNEJ PRAWA PRACY (2016-2018) W KONTEKŚCIE ZASADY WOLNOŚCI PRACY ${ }^{1}$}

\begin{abstract}
Abstrakt
Przedmiot badań: Artykuł dotyczy wybranych propozycji legislacyjnych Komisji Kodyfikacyjnej Prawa Pracy w latach 2016-2018, związanych z wolnością pracy. Autorka, będąca uczestniczką posiedzeń Komisji, prezentuje wybrane rozwiązania zawarte w projekcie kodeksu pracy. Zwraca uwagę na ich niezgodność z zasadą wolności pracy. Krytycznie ocenia propozycję ograniczenia wyboru podstawy zatrudnienia, a także nowe umowy o pracę. Zwraca uwagę na zagrożenia praktyczne związane $\mathrm{z}$ ich wejściem w życie.

Cel badawczy: Analiza wybranych regulacji zawartych w projekcie kodeksu pracy z punktu widzenia zasady wolności pracy. Ocena ich wpływu na prawo pracy i rynek pracy. Porównanie z obowiązującymi i wcześniejszymi regulacjami kodeksu pracy, a także z rozwiązaniami obowiązującymi w krajach Europy Zachodniej.

Metoda badawcza: Analityczna, historyczna, komparatystyczna (porównawcza).

Wnioski: Negatywna ocena niektórych propozycji zawartych w projekcie kodeksu pracy z uwagi na naruszenie zasady wolności pracy.

Słowa kluczowe: Komisja Kodyfikacyjna Prawa Pracy, kodeks pracy, wolność pracy, zakaz konkurencji, umowa o pracę.

* Dr hab., prof. UKSW, Uniwersytet Kardynała Stefana Wyszyńskiego w Warszawie, Wydział Prawa i Administracji, Katedra Prawa Pracy; e-mail: gladoch_law@wp.pl

1 Artykuł jest rozszerzoną wersją referatu przygotowanego na IX Seminarium Szubertowskie nt. Indywidualne prawo pracy - propozycje i tendencje zmian. Seminarium to, zorganizowane przez Zakład Europejskiego i Zbiorowego Prawa Pracy i Katedrę Prawa Pracy i Ubezpieczeń Społecznych UŁ, odbyło się 19 października 2018 r.
\end{abstract}




\section{Wstęp}

Komisja Kodyfikacyjna działała w latach 2016-2018 jako organ powołany na mocy Rozporządzenia Rady Ministrów z dnia 9 sierpnia 2016 r. w sprawie Komisji Kodyfikacyjnej Prawa Pracy² $^{2}$. Akt ten określał przedmiot działania organu, jego skład i tryb postępowania oraz sposób finansowania i obsługi Komisji. Zgodnie z $§ 8$ pkt 1 rozporządzenia do zadań Komisji należało opracowanie projektu ustawy - Kodeks pracy wraz z uzasadnieniem i projektu ustawy - Kodeks zbiorowego prawa pracy wraz z uzasadnieniem. W niniejszej publikacji zamierzam odnieść się do wybranych propozycji zawartych w pierwszym z wymienionych projektów, jako nowych koncepcji w prawie pracy. Analiza całości regulacji nie jest możliwa, dlatego dokonam jej przede wszystkim z punktu widzenia zasady wolności pracy jako reguły konstytucyjnej. Stanowi ona bowiem podstawowy standard tworzenia prawa regulującego tzw. rynek pracy. Będąc uczestnikiem żmudnych prac Komisji, mam pełną świadomość, że projekty nie są gotowym aktem legislacyjnym. Stworzenie gotowego aktu legislacyjnego nie było bowiem możliwe w trakcie niespełna 18 miesięcy pracy Komisji. Projekt kodeksu pracy zawiera jednak bardzo konkretne przepisy zamieszczone w 544 artykułach. Nie ulega wątpliwości, iż nawet mimo pewnych niedociągnięć dotyczących sztuki legislacyjnej ${ }^{3}$ można dokonać ich oceny. Tak też postrzega rezultat swoich prac sama Komisja Kodyfikacyjna, w uzasadnieniu do projektu pisząc m.in.: „Krótki, a właściwie ekspresowy jak na tak złożoną materię, czas na prace nad projektem Kodeksu ma ten skutek, że walorem projektu jest przede wszystkim wskazanie konstrukcji prawnych"4.

Z uwagi na tytuł opracowania rozważania zostaną ograniczone do konkretnych instytucji, takich jak: nakaz zatrudnienia pracowniczego, „domniemanie” stosunku pracy, katalog nowych umów o pracę i zakaz konkurencji.

Dz.U. z 30.08.2016 r., poz. 1366.

Rozporządzenie Prezesa Rady Ministrów z dnia 20 czerwca 2002 r. w sprawie „Zasad techniki prawodawczej" (Dz.U. z 2002 r., nr 100, poz. 908).

4 Uzasadnienie zostało zamieszczone na stronie: https://www.gov.pl/web/rodzina/bip-tekstyprojektu-kodeksu-pracy-i-projektu-kodeksu-zbiorowego-prawa-pracy-opracowane-przezkomisje-kodyfikacyjna-prawa-pracy 


\section{Zasada wolności pracy}

Zasada wolności pracy zawarta w Konstytucji RP stanowi podstawową normę ochronną, mieszczącą się w kategorii praw człowieka. Jak słusznie zauważono w literaturze, jest ona „wartością o podstawowym znaczeniu dla jednostek nie tylko ze względu na możliwość zapewnienia sobie i swojej rodzinie bytu, ale także ze względu na możliwość samorozwoju"s. Zgodnie z art. 65 ust. 1 ustawy zasadniczej każdemu zapewnia się wolność wyboru i wykonywania zawodu oraz wyboru miejsca pracy. Wyjątki określa ustawa. W ocenie Trybunału Konstytucyjnego zasada wolności pracy w ujęciu pozytywnym obejmuje zarówno możliwość wyboru rodzaju pracy - aspekt kwalifikacyjny, wyboru pracodawcy - aspekt podmiotowy, jak i decydowania o miejscu zatrudnienia - aspekt przestrzenny ${ }^{6}$. Zdaniem doktryny, na wolność pracy w płaszczyźnie prawnej składają się: 1) swoboda zawarcia stosunku pracy, a w jej obrębie wolność zarówno podjęcia, jak i niepodjęcia zatrudnienia oraz wyboru rodzaju umowy o pracę lub innej podstawy stosunku pracy; 2) swoboda doboru kontrahenta (obejmująca także wybór zawodu i miejsca pracy) oraz 3) swoboda rozwiązania stosunku pracy $^{7}$. M. Tomaszewska postrzega wolność pracy jako kategorię niejednorodną, na którą składa się wolność negatywna, wyrażająca pracę dobrowolną oraz wolność pozytywna, pod którą „kryją się z kolei warunki umożliwiające dokonanie swobodnego wyboru pracodawcy i rodzaju pracy, miejsca pracy [...], elastyczność kształtowania treści łączącego strony stosunku pracy, ewentualność rozwiązania umowy przez każdą ze stron przy zachowaniu reguł ochrony pozycji pracownika"8. T. Liszcz akcentuje wymiar aksjologiczny wolności pracy, podkreślając, iż „wolność pracy w aspekcie negatywnym zabrania władzom publicznym stwarzania nieuzasadnionych przeszkód w swobodnym wyborze zawodu, rodzaju pracy i pracodawcy"'.

Tak A. Śledzińska-Simon, Wolność pracy, w: M. Jabłoński (red.), Realizacja i ochrona konstytucyjnych wolności i praw jednostki w polskim porzadku prawnym, E-Wydawnictwo. Prawnicza i Ekonomiczna Biblioteka Cyfrowa, Wrocław 2014, s. 573.

6 Por. wyrok TK z dnia 26 kwietnia 1999 r., K. 33/98, OTK 1999, Nr 4, poz. 71 oraz wyrok TK z dnia 23 czerwca 1999 r., K. 30/98, OTK 1999, Nr 5, poz. 101.

7 Tak A. Patulski, Wolność pracy - próba ujęcia wielopłaszczyznowego, Wydawnictwa Uniwersytetu Warszawskiego, Warszawa 1992, s. 15.

8 Por. M. Tomaszewska, Zasada wolności pracy w europejskim prawie wspólnotowym, Ars boni et aequi, Poznań 2003, s. 97.

9 Por. T. Liszcz, Aksjologiczne podstawy prawa pracy, w: K.W. Baran (red.), System prawa pracy, Tom I: Cześć ogólna, Wolters Kluwer Polska, Warszawa 2017, s. 218. 
Zasada wolności pracy w powyższym ujęciu odgrywa kluczową rolę w procesie kształtowania norm prawa pracy, gdyż wyznacza granice przy nawiązaniu stosunku pracy (a nawet szerzej - stosunku zatrudnienia), kształtowaniu treści, a także rozwiązaniu tego stosunku. Zarazem mieści w sobie inne kluczowe wolności, obowiązujące $\mathrm{w}$ państwie prawa. W doktrynie dostrzeżono związek wolności pracy z wolnością gospodarczą. J. Markiewicz-Stanny zauważa, że jeśli wolność pracy będziemy postrzegać szeroko, jako ogólne określenie wolności aktywności zawodowej, to w takim ujęciu jest ona bliska pojęciu wolności gospodarczej. Zarazem cytowana autorka wyjaśnia, że wolność gospodarcza, jako zasada ogólna, jest różnie definiowana, również w taki sposób, że „obejmuje ona swobodę zarobkowania i swobodę wyboru zawodu"10. Podkreśla jednak, że nie są to wolności tożsame, choćby dlatego, że z wolności działalności gospodarczej mogą korzystać także osoby prawne, podczas gdy wolność pracy jest dedykowana wyłącznie osobom fizycznym.

Nie ulega wątpliwości, że rozwiązania przyjęte przez państwo, w tym regulacje określające prawne formy zatrudnienia czy zasady dotyczące wykonywania zawodu, wytyczają ramy wolności indywidualnej i są podejmowane albo $\mathrm{w}$ interesie osób wykonujących zawód/zatrudnionych albo w interesie ogółu ${ }^{11}$. Właśnie z tej z perspektywy - działań na rzecz zatrudnionych, zostanie dokonana ocena propozycji rozwiązań zawartych w projekcie kodeksu pracy.

\section{Ograniczenie wyboru podstawy zatrudnienia w projekcie kodeksu pracy}

Jednym z wiodących celów nowej kodyfikacji było ograniczenie liczby umów prawa cywilnego na rynku pracy. W uzasadnieniu projektu kodeksu pracy wyjaśniono, iż zmierza on ku realizacji kilku głównych postulatów, do których należy w szczególności „,wprowadzenie rozwiązań minimalizujących zjawisko zatrudniania na podstawie tzw. umów zlecenia, w zamian za wprowadzenie elastycznych typów umów o pracę dotyczących prac krótkoterminowych"12. Proces „minimalizowania” patologii na rynku pracy polegać miał na niemal cał-

10 J. Markiewicz-Stanny, Wolność pracy ludzkiej. Studium z zakresu praw człowieka, Oficyna Wydawnicza Uniwersytetu Zielonogórskiego, Zielona Góra 2015, s. 44.

11 A. Śledzińska-Simon, op. cit., s. 573.

12 Plik do pobrania w formacie doc. dostępny na stronie: https://www.gov.pl/web/rodzina/bipteksty-projektu-kodeksu-pracy-i-projektu-kodeksu-zbiorowego-prawa-pracy-opracowaneprzez-komisje-kodyfikacyjna-prawa-pracy 
kowitym zakazie zawierania umów prawa cywilnego na rzecz umowy o pracę, przy jednoczesnym wprowadzeniu specyficznej konstrukcji prawnej, nazwanej w projekcie „domniemaniem stosunku pracy”.

$\mathrm{Na}$ mocy art. 48 projektu praca na innej postawie niż stosunek pracy (tj. według projektu - na podstawie umowy o zatrudnieniu niepracowniczym) jest dopuszczalna jedynie $\mathrm{w}$ kilku enumeratywnie wymienionych przypadkach, spełniających następujące przesłanki: praca polega w dominującej części na przekazywaniu lub stosowaniu wiedzy specjalistycznej lub jest pracą osób zarządzających, o ile osoby wykonujące te prace osiągają średnie dochody za godzinę pracy w wysokości co najmniej 5-krotności stawki godzinowej wynikającej z minimalnego wynagrodzenia za pracę, określonego na podstawie przepisów odrębnych. Ograniczenia te zostały jednak złagodzone $\mathrm{z}$ uwagi na potrzeby pracowników wynikające $\mathrm{z}$ potrzeby dodatkowego zarobkowania poza stosunkiem pracy. Zgodnie z projektem dopuszczalne jest zatrudnienie niepracownicze także $\mathrm{w}$ przypadku pracy okazjonalnej wykonywanej w wymiarze do 32 godzin w miesiącu, niebędącej pracą szczególnie niebezpieczną, i pracy wykonywanej w ramach organów osoby prawnej. Propozycje dotyczące zarówno wysokości stawki godzinowej, jak też dopuszczalnej liczby godzin pracy poza stosunkiem pracy nie były poparte żadnymi wyliczeniami lub danymi ekonomicznymi. Zostały podane jako propozycja do dalszej pracy ekspertów w zespole prawa pracy Rady Dialogu Społecznego. Okoliczności wprowadzenia opisanych wyjątków również były raczej dość nietypowe, bowiem zostały one przegłosowane przez członków Zespołu do spraw opracowania projektu kodeksu pracy tuż przed ostatecznym głosowaniem projektu przez wszystkich uczestników Komisji Kodyfikacyjnej. Kontekst podejmowania decyzji w tak kluczowych kwestiach dla rynku pracy dowodzi, że czas na przygotowanie projektu był zdecydowanie zbyt krótki. Zabrakło rzeczowej i pogłębionej dyskusji nad zaprojektowanymi zmianami, mimo że miały one charakter przełomowy dla prawa pracy. Nie ulega wątpliwości, że zaproponowane regulacje w istotny sposób ingerowały $\mathrm{w}$ inne przepisy obowiązujące $\mathrm{w}$ systemie prawa, przede wszystkim zaś w swobodę umów.

Przedstawiona propozycja Komisji, mająca na celu ograniczenie liczby umów prawa cywilnego miała realizować z gruntu słuszną ideę, tyle że w swym wyrazie zbyt daleko idącą, a wręcz radykalną, czyniąc ją nierealną do zastosowania. Proces zmian na rynku pracy następował przez kilkadziesiąt lat za przyzwoleniem tak ustawodawcy, jak i judykatury. Prawo zawierania umów prawa cywilnego zostało usankcjonowane w przepisach i w wykładni Sądu Najwyższego, tak że obecnie coraz powszechniej używa się określenia „,prawo za- 
trudnienia" zamiast prawa pracy. Zdaniem niektórych autorów rozstrzygnięcia sięgają już tak dalece, o czym świadczyć ma najnowsze orzecznictwo Sądu Najwyższego, iż wola stron może zmienić podstawę zatrudnienia z umowy o pracę na umowę cywilnoprawną ${ }^{13}$.

Opisane zjawisko w literaturze przedmiotu nazwano polską ,trzecią drogą”, której specyfika polega nie tylko na wzrastającej liczbie tych umów w sferze zatrudnienia, lecz także na ich zawieraniu bez potrzeby i konieczności prowadzenia działalności gospodarczej ${ }^{14}$. Rodzime rozwiązania różnią się zatem tym, że osoba podpisująca umowę-zlecenie nie musi być przedsiębiorcą, odmiennie niż w krajach zachodnioeuropejskich, gdzie umowy prawa cywilnego są zawierane zasadniczo z przedsiębiorcami. Celem Komisji było zatem zwrócenie uwagi także na konieczność upowszechnienia obowiązku rejestracji działalności gospodarczej, co było pierwotnie zapisane w projekcie, jednakże z pomysłu tego zrezygnowano przede wszystkim z uwagi na trudności praktyczne $\mathrm{z}$ wyegzekwowaniem tego obowiązku ${ }^{15}$. Ostatecznie, na podstawie art. $7 \S 4$ do projektu wprowadzono definicję samozatrudnionego, z której wynika prawo wykonywania pracy także poza działalnością gospodarczą.

Konsekwencją rozwoju tzw. „polskiej drogi” są przepisy zmienionej ustawy z 23 maja 1991 r. o związkach zawodowych ${ }^{16}$, która w art. 1 przyznaje prawo koalicji wszystkim zatrudnionym, wprowadzając pojęcie osoby zatrudnionej (a nie jak dotąd pracownika). Na mocy art. 2 ust. 1 tej ustawy prawo tworzenia i wstępowania do związków zawodowych przysługuje osobom wykonującym pracę zarobkową. Zgodnie $\mathrm{z}$ art. $1^{1} \mathrm{pkt} 1$ ) osoba wykonująca pracę zarobkową oznacza pracownika lub osobę świadczącą pracę za wynagrodzeniem na innej podstawie niż stosunek pracy, jeżeli nie zatrudnia do tego rodzaju pracy innych osób, niezależnie od podstawy zatrudnienia, oraz ma takie prawa

13 Tak A.W. Świątkowski, Prawo wyboru podstawy zatrudnienia, Studia Iuridica Lublinensia 2015/XXIV/3, s. 244.

14 Por. A. Sobczyk, Podmiotowość pracy i towarowość ustug, Wolters Kluwer S.A., Kraków 2018, s. 33 i n.

15 Por. wybrane wypowiedzi w prasie, m.in. Kolejne propozycje z nowego kodeksu pracy: zakaz dorabiania do etatu, Puls HR, plik do pobrania w formacie doc. dostępny na stronie: https:// www.pulshr.pl/prawo-pracy/kolejne-propozycje-z-nowego-kodeksu-pracy-zakaz-dorabianiado-etatu,51011.html; Pracowniku, jeśli chcesz dorabiać, załóż działalność. Kolejna kontrowersyjna propozycja Komisji Kodyfikacyjnej, Money.pl, plik do pobrania w formacie doc. dostępny na stronie: https://www.money.pl/gospodarka/wiadomosci/artykul/prawo-pracy-komisja-kodyfikacyjnazlecenia-,11,0,2398219.html

16 Ustawa z dnia 5 lipca 2018 r. o zmianie ustawy o związkach zawodowych oraz niektórych innych ustaw (Dz.U. z 22 sierpnia 2018 r., poz. 1608) art. 1 pkt 1 i 2. 
i interesy związane $\mathrm{z}$ wykonywaniem pracy, które mogą być reprezentowane i bronione przez związek zawodowy. $Z$ kolei, na mocy art. art. $1^{1}$ pkt 2) pracodawcą jest pracodawca w rozumieniu art. 3 ustawy z dnia 26 czerwca $1974 \mathrm{r}$. - kodeks pracy oraz jednostka organizacyjna, choćby nie posiadała osobowości prawnej, a także osoba fizyczna, jeżeli zatrudniają one inną niż pracownik osobę wykonującą pracę zarobkową, niezależnie od podstawy tego zatrudnienia. Innym jednoznacznym wyrazem akceptacji obecności umów prawa cywilnego w sferze zatrudnienia jest ustawa $\mathrm{z}$ dnia 10 października 2002 r. o minimalnym wynagrodzeniu za pracę ${ }^{17}$. Zgodnie z art. 1 pkt 1a) ,minimalna stawka godzinowa" oznacza minimalną wysokość wynagrodzenia za każdą godzinę wykonania zlecenia lub świadczenia usług, przysługującą przyjmującemu zlecenie lub świadczącemu usługi.

Mając na uwadze powyższe regulacje, należy dojść do wniosku, że ustawodawca nie tylko nie stara się powstrzymać zjawiska upowszechnienia umów prawa cywilnego, lecz wręcz stan ten sankcjonuje. W doktrynie prawa pracy coraz częściej mówi się o „ekspansji prawa pracy”, a zatem upatruje się w zjawisku $\mathrm{z}$ istoty negatywnym jego aspektu pozytywnego, który polega na rozprzestrzenianiu się norm ochronnych prawa pracy na sferę stosunków cywilnoprawnych. Opisana powyżej ,polska droga” prawa zatrudnienia przechodzi kolejny etap rozwoju, który został zaakceptowany w przepisach. Mówiąc inaczej - wybór został już dokonany, a zadaniem ustawodawcy jest ograniczenie zjawisk patologicznych związanych z próbą wyzysku. Logiczne wydaje się zatem stwierdzenie, że nie sposób powstrzymać zmian, które nastąpiły na wiele lat wcześniej przed rozpoczęciem prac nad nowym kodeksem ${ }^{18}$.

Tymczasem Komisja Kodyfikacyjna postanowiła $\mathrm{z}$ tej drogi zawrócić, przyjmując radykalne rozwiązanie, polegające na maksymalnym ograniczeniu umów prawa cywilnego na rynku pracy. Skrajność niektórych rozwiązań zawartych w projekcie kodeksu pracy budzi uzasadnione wątpliwości z punktu widzenia konstytucyjnej zasady wolności pracy. Wiąże się ona z próbą przymuszania osób podejmujących zatrudnienie do wyboru konkretnej podstawy wykonywania pracy lub usług, niejako ignorując ich potrzeby, a zarazem pozbawiając ich wolności optymalnego dla nich wyboru. Problem ten jest jednak dużo bardziej skomplikowany. Wiąże się on bowiem z oceną, czy umowa o pracę jest w każdej sytuacji bardziej korzystna od umowy prawa cywilnego. W piśmiennictwie

T.j. Dz.U. z 2018 r., poz. 2177.

18 Na ten aspekt prac Komisji zwróciłam uwagę w artykule Prawo wyboru podstawy zatrudnienia w kontekście zasady swobody prowadzenia działalności gospodarczej, PiZS 2018/3, s. 5. 
od dawna zwraca się uwagę na szerszą sferę wolności osób wykonujących pracę w ramach umów prawa cywilnego. Jest ona świadczona samodzielnie zarówno w sensie organizacyjnym (bez kierowania poleceń), jak i majątkowym (osoby te dysponują środkami niezbędnymi do wykonywania pracy objętej przedmiotem umowy) ${ }^{19}$.

Dyskusja nabiera całkiem innego wymiaru, kiedy uwzględni się dokonujące się przemiany technologiczne i społeczne, a także potrzeby zatrudnionych, które wcześniej nie występowały wcale lub pojawiały w dużo mniejszym zakresie niż obecnie. Potrzeba wolności człowieka dotyczy również, a w sferze zatrudnienia - przede wszystkim, wyboru podstawy i sposobu świadczenia pracy. Niestety, ani obecnie obowiązujący Kodeks pracy, ani projekt nowego zaprezentowany przez Komisję Kodyfikacyjną z lat 2016-2018 nie uwzględnia oczekiwań pracowników w zakresie organizacji pracy, w tym elastyczności kształtowania czasu pracy, zasad udzielania urlopu wypoczynkowego czy też sposobu świadczenia pracy. W konsekwencji przepisy Kodeksu pracy, nawet z ich socjalnym i ochronnym charakterem, nie dla wszystkich są na tyle atrakcyjne, żeby stanowić zachętę do zatrudnienia na podstawie umowy o pracę. Jak słusznie zauważa I. Boruta, istotnym problemem współczesnego prawa pracy jest „kondycja prawa socjalnego”. Autorka zdiagnozowała problem niedostosowania prawa socjalnego do dzisiejszej rzeczywistości. W jej ocenie „prawo to koresponduje $\mathrm{w}$ większym stopniu z przemysłową produkcją, a więc innymi czasami niż obecne" ${ }^{20}$. Na nowo więc należy przemyśleć ideę prawa socjalnego, co rodzi potrzebę nowego spojrzenia na model pracy, w tym podporządkowanie pracownika poprzez weryfikację fundamentalnych pojęć dla prawa pracy ${ }^{21}$. Przedstawiciele doktryny zdają sobie sprawę z potrzeby przewartościowania utartych koncepcji w prawie pracy, w tym również funkcji ochronnej, wszak potrzeby zatrudnionych zmieniły się i ciągle ewoluują. Gwarancje socjalne, stanowiące fundament prawa pracy nie są jedyną i najważniejszą potrzebą na rynku pracy, szczególnie wówczas, kiedy można ją sobie zapewnić we własnym zakresie, także poza zatrudnieniem pracowniczym.

Trudno nie zgodzić się z coraz częstszą opinią wśród przedstawicieli nauki, że nie tylko zasadne, ale wręcz konieczne jest obowiązywanie w systemie umów związanych z zatrudnieniem, również umowy zlecenia i umowy o świadczenie

19 Por. I. Florczak, Status prawny osób świadczacych pracę w ramach umownego zatrudnienia nietypowego, Wydawnictwo Uniwersytetu Łódzkiego, Łódź 2017, s. 41.

20 Por. I. Boruta, Pracować nad lepsza przyszłością. W sprawie raportu Światowej Komisji ds. przyszłości pracy (MOP), PiZS 2019/3, s. 6-7.

${ }^{21}$ Ibidem, s. 7. 
usług, co jest zresztą niezbędne z uwagi na charakter świadczonych usług (wykonywanych czynności). Ma ona zarazem charakter pierwotny w tym sensie, że wynika z istoty i przeznaczenia tych umów. Nie ulega wątpliwości, że charakter świadczonych usług jest niezwykle zróżnicowany. Tymczasem przedstawiona powyżej propozycja Komisji Kodyfikacyjnej jedynie w części uwzględnia różnice w charakterze świadczonej pracy i potrzebę odmienności ich prawnej regulacji, tak jakby każda usługa wiązała się zawsze z przekazywaniem lub stosowaniem wiedzy specjalistycznej. Nierzadko przecież może ona polegać na sprzedaży umiejętności (zdolności), a niekoniecznie wiedzy, o czym świadczy zatrudnienie sportowców ${ }^{22}$, artystów czy rzemieślników. Przepis wprowadza dodatkowy wymóg, dotyczący wysokości otrzymywanego dochodu, co dla niektórych usług nie ma większego znaczenia. Chodzi o to, że tzw. freelancerzy potrzebują przede wszystkim wolności, której przez liczne ograniczenia nie daje im Kodeks pracy. Prawo do wyboru podstawy zatrudnienia innej niż umowa o pracę nie musi bowiem wynikać z przymusu ekonomicznego, lecz z potrzeby wolności ${ }^{23}$.

Zamierzeniem Komisji było zarazem wzmocnienie sądów w procesach o ustalenie stosunku pracy polegające na ułatwieniu rozstrzygania na korzyść potencjalnych pracowników. Jak czytamy w uzasadnieniu projektu kodeksu: „Komisja zwraca uwagę, że w tej niezmiernie ważnej dla praw jednostki kwestii nie odbyła się w Polsce pogłębiona debata społeczna, co w praktyce jest źródłem trudności dla wymiaru sprawiedliwości w kontekście tzw. zatrudnienia cywilnego. [...] Na gruncie obowiązującego stanu prawnego możliwe jest uznanie przez judykaturę, że umowy określane jako cywilnoprawne są de facto umowami o pracę, z wszystkimi konsekwencjami takiego stanu rzeczy. Powyższe wprowadza stan niepewności prawnej tak dla pracującego, jak i dla pracodawcy”. Komisja, zamierzając skutecznie ograniczyć dalszą praktykę zawierania umów prawa cywilnego, postanowiła wprowadzić specyficzną konstrukcję prawną, nazwaną „domniemaniem stosunku pracy”. W istocie jednak

22 W orzecznictwie jako nienazwaną umowę o świadczenie usług zakwalifikowano zawodowy kontrakt na profesjonalne uprawianie piłki nożnej (zob. postanowienia SN z dnia 10 marca 2010 r., II UK 363/09, LEX nr 577467, oraz z dnia 12 marca 2010 r., II UK 400/09, LEX nr 577468). Umowa ta obliguje zawodnika profesjonalnego do dołożenia należytej staranności i świadczenia usługi w taki sposób, by maksymalizować swoje osiągnięcia sportowe, a przez wpływać na wyniki swojego klubu sportowego. Oczywistym jest, że nie polega ona na wiedzy.

23 Por. szerzej M. Gladoch, Prawo wyboru podstawy zatrudnienia w kontekście zasady swobody prowadzenia działalności gospodarczej, PiZS 2018/3, s. 5. 
nie zawiera ona typowych cech domniemania, lecz stwarza raczej osobliwe rozwiązanie sprowadzające się do przerzucenia ciężaru dowodu na pracodawcę. $\mathrm{Na}$ mocy art. 50 projektu istotne wątpliwości dotyczące ustalenia, czy praca jest wykonywana $\mathrm{w}$ formie zatrudnienia, czy samozatrudnienia, sąd rozstrzyga na korzyść zatrudnienia. Pracodawca zaprzeczający istnieniu stosunku pracy ma obowiązek przeprowadzenia dowodu, że praca nie jest wykonywana pod jego kierownictwem. W praktyce spełnienie obowiązku udowodnienia, że praca nie miała cech kierownictwa przełożonego mogłoby okazać się niewykonal$\mathrm{n}^{24}$. Trzeba bowiem przypomnieć, że pojęcie kierownictwa występuje także w stosunkach prawa cywilnego, co oznacza, że nie jest to określenie charakterystyczne wyłącznie dla prawa pracy. Zgodnie z art. 430 Kodeksu cywilnego kto na własny rachunek, powierza wykonanie czynności osobie, która przy wykonywaniu tej czynności podlega jego kierownictwu i ma obowiązek stosować się do jego wskazówek, ten jest odpowiedzialny za szkodę wyrządzoną z winy tej osoby przy wykonywaniu powierzonej jej czynności. Warto zwrócić uwagę także na liczne wypowiedzi judykatury dotyczące pojęcia kierownictwa. Sąd Najwyższy zauważył, że również w umowie-zleceniu mogą wystąpić cechy kierownictwa i podporządkowania, choć nie wyjaśnił różnic dotyczących sposobu świadczenia pracy w ramach wskazanych typów umów ${ }^{25}$. Jest to zresztą zadanie niełatwe, biorąc pod uwagę wiele cech wspólnych kierownictwa na gruncie prawa cywilnego i prawa pracy. W tym miejscu warto przytoczyć wyrok Sądu Apelacyjnego w Łodzi z dnia 20 kwietnia 2017 r., w którym stwierdzono, że decydujące znaczenie dla przyjęcia odpowiedzialności z art. 430 k.c. ma istnienie stosunku zwierzchnictwa pomiędzy powierzającym a wykonawcą czynności ${ }^{26}$. W ocenie sądu ,chodzi tu więc o taki układ relacji, który ze swej istoty zakłada podległość wykonawcy wobec powierzającego, a więc obowiązek stosowania się do jego wskazówek". Z kolei Sąd Apelacyjny w Warszawie stwierdził, iż „oczywista w przypadku lekarza autonomia w zakresie czynności zawodowych nie stoi na przeszkodzie uznaniu, iż działa on jako podwładny w kontekście stanowiącego podstawę odpowiedzialności art. 430 k.c."27 Sąd Najwyższy w zakresie umowy o świadczenie usług medycznych powołał się na przesłankę zależności organizacyjnej, pisząc, że ,istniejące organizacyjne podporząd-

\footnotetext{
$24 \mathrm{Na}$ te problemy wskazywałam w zdaniu odrębnym zgłoszonym do projektu kodeksu pracy. Plik do pobrania w formacie doc. dostępny na stronie: https://www.prawo.pl/kadry/monikagladoch-wyjasnia-dlaczego-zaglosowala-przeciw-projektom-kodeksow-pracy,267030.html

25 Por. wyrok SN z dnia 11 września 2013 r., II PK 372/12.

26 LEX nr 2310622.

27 Por. wyrok SA z dnia 15 czerwca 2016 r., LEX nr 2099909.
} 
kowanie lekarza usprawiedliwia co do zasady odpowiedzialność na podstawie art. 430 k.c. niepublicznego zakładu opieki zdrowotnej za szkodę wyrządzoną $\mathrm{z}$ winy tego lekarza" ${ }^{28}$. Różnica pomiędzy podporządkowaniem pracowniczym a kierownictwem w umowie cywilnoprawnej nie zawsze jest oczywista, a niekiedy staje się wręcz nieuchwytna, co ma miejsce w szczególności w przypadku świadczenia pracy bądź usług przez personel medyczny. W następstwie obowiązywania zaproponowanych przez Komisję regulacji mogłoby dojść do sytuacji, w której prawie każde zatrudnienie na podstawie umowy prawa cywilnego obarczone byłoby ryzykiem ustalenia stosunku pracy.

\section{Nowe umowy o pracę a wolność pracy}

Komisja przyjęła, w mojej ocenie, z gruntu błędne założenie, że rozpowszechnienie tzw. umów zlecenia wynika z braku odpowiednio elastycznych form zatrudnienia, czyli niewystępowania umów o pracę, które można by było łatwo nawiązać i rozwiązać. Hipoteza ta bazuje na bardzo dużym uproszczeniu, nieuwzględniającym sfery wolności osoby świadczącej pracę, która wykracza poza ten schemat. Jak wyjaśniłam powyżej, wybór niepracowniczej podstawy zatrudnienia wiąże się przede wszystkim ze stylem pracy, odmiennym niż w relacji pracownik - pracodawca, któremu nie każdy jest w stanie się podporządkować, choćby z uwagi na odmienne cechy osobowości. Kierując się założeniem wynikającym $\mathrm{z}$ upowszechnienia elastycznych podstaw zatrudnienia, Komisja złożyła propozycję nowych, „łatwo wypowiadalnych umów o pracę” na czas wykonywania pracy dorywczej, na czas wykonywania pracy sezonowej oraz na czas wykonywania pracy na podstawie nieetatowej umowy o pracę. To ostatnie rozwiązanie zostało przewidziane wyłącznie dla uczących się oraz dorabiających osób starszych.

Najwięcej kontrowersji wzbudza tzw. nieetatowa umowa o pracę, której konstrukcja może rodzić wiele wątpliwości praktycznych. Zgodnie z art. 84 projektu umowa o pracę, której przedmiotem jest praca nieprzekraczająca 20 godzin na tydzień, wykonywana przez pracownika będącego studentem do końca roku kalendarzowego, w którym kończy on 26 lat albo przez pracownika od początku roku kalendarzowego, w którym kończy on 60 lat, może być realizowana bez obowiązku zapewnienia pracownikowi minimalnej liczby godzin pracy oraz bez obowiązku stawienia się pracownika do pracy, dopóki pracownik

28 Por. wyrok z dnia 20 maja 2016 r., OSNC-ZD 2018/2/19. 
i pracodawca nie dokonają takiego uzgodnienia (nieetatowa umowa o pracę). Pracownik ma obowiązek stawienia się do pracy, a pracodawca ma obowiązek zapewnienia pracownikowi pracy, jeżeli strony dokonały takiego uzgodnienia w terminie nie dłuższym niż 7 dni przed dniem rozpoczęcia wykonywania pracy. Nieetatowa umowa o pracę może określać krótszy termin. Powyższa regulacja nawiązuje do koncepcji występującej w prawie brytyjskim, dotyczącej zatrudnienia tzw. workera ${ }^{29}$. Jest ona całkowicie obca polskiemu systemowi prawa, o czym świadczy przywołana konstrukcja prawna.

Propozycja nowych umów o pracę nie poszerza sfery wolności pracy. Związek nowych umów z prawem pracy jest raczej dość przypadkowy, a ich charakter nawiązuje bardziej do cywilistycznych konstrukcji umów, w tym przede wszystkim umowy świadczenia usług. Nowe rodzaje umów nie gwarantują bowiem żadnej ochrony przewidzianej w ramach obowiązujących standardów zatrudnienia pracowniczego, tym samym zaprzeczając dotychczasowemu dorobkowi tej gałęzi prawa.

Zgodnie z art. 88 projektu do pracowników zatrudnionych na podstawie umowy o pracę na czas wykonywania pracy dorywczej, na czas wykonywania pracy sezonowej oraz na podstawie nieetatowej umowy o pracę nie stosuje się szczególnej ochrony przed wypowiedzeniem lub rozwiązaniem umowy o pracę, wynikającej z przepisów szczególnych, a także przepisów odrębnych. Okres wypowiedzenia nowych umów o pracę wynosi odpowiednio 3 dni, tydzień lub dwa tygodnie. Jest on zatem nieproporcjonalnie krótki w porównaniu z umową na czas określony lub na czas nieokreślony. Analiza treści zaproponowanych przepisów prowokuje pytanie o sens ich wprowadzenia, skoro nowe umowy o pracę niewiele różnią się od umów cywilnych, przynajmniej gdy chodzi o ochronę zatrudnienia.

\section{Regulacja zakazu konkurencji w projekcie kodeksu pracy}

Najdalej idące rozwiązania prawne ograniczające zasadę wolności pracy wynikają z projektu przepisów dotyczących zakazu konkurencji. Jak wyjaśniono wcześniej, jednym z kluczowych elementów wolności pracy jest prawo wyboru pracodawcy. Zdaniem Trybunału Konstytucyjnego z tej wolności wynika „generalny zakaz adresowany do władz publicznych, wprowadzania ograniczeń w swobodnym decydowaniu przez jednostkę o podjęciu, kontynuowaniu i za-

Por. szerzej A. Sobczyk, op. cit., s. 156 i n.; A. Musiała, Zatrudnienie niepracownicze, Difin, Warszawa 2011, s. 76 i n. 
kończeniu pracy w określonym zawodzie, o miejscu i rodzaju wykonywanej pracy oraz o wyborze pracodawcy"30. Innymi słowy, nie należy ograniczać prawa do dodatkowego zatrudnienia, jeśli nie sprzeciwia się ono dobru zakładu pracy, czyli nie naraża pracodawcę na powstanie szkody. W piśmiennictwie wyjaśniono, że pracownik objęty zakazem konkurencji nie może prowadzić działalności, która spełnia łącznie dwie przesłanki: jest działalnością konkurencyjną w sensie obiektywnym, tzn. działalnością, która zagraża lub narusza interes pracodawcy, a zarazem prowadzenie tej działalności, z mocy postanowień umowy, zostało uznane za zabronione ${ }^{31}$. Warto w tym miejscu wspomnieć o uchylonym przepisie kodeksu pracy, który wolność tę ograniczał w sposób, który Trybunał Konstytucyjny uznał za niedopuszczalny. Zgodnie z nieobowiązującym art. 101 k.p. pracownik zatrudniony w pełnym wymiarze czasu pracy nie mógł podejmować dodatkowego zatrudnienia bez zgody zakładu pracy, jeżeli przepis szczególny nie stanowił inaczej ${ }^{32}$. Wydaje się, że Komisja nawiązała do zamierzchłej regulacji, przewidując bardzo podobny przepis z jednej strony gwarantujący pracownikowi ograniczone odszkodowanie, z drugiej - dopuszczający ustanowienie kary umownej za naruszenie zakazu. Na mocy art. 245 projektu kodeksu pracy w zakresie określonym w odrębnej umowie, zawartej z pracodawcą zatrudniającym pracownika w pełnym wymiarze czasu pracy, pracownik nie może prowadzić innej działalności gospodarczej ani też podejmować innej pracy zarobkowej, w zamian za określone w umowie dodatkowe miesięczne wynagrodzenie nie wyższe niż minimalne wynagrodzenie za pracę, ustalane na podstawie przepisów odrębnych. Umowa może przewidywać karę umowną z tytułu niewykonania lub nienależytego wykonywania umowy, nie wyższą niż 3-krotność wynagrodzenia zasadniczego pracownika. Propozycja ma bardzo szeroki zakres, ponieważ nie obejmuje wyłącznie wykonywania przez pracownika pracy konkurencyjnej, lecz jakiejkolwiek. Wymaga ona w każdym przypadku zawarcia umowy, co tym bardziej ogranicza konstytucyjną zasadę wolności pracy, gdyż odstręcza od zawarcia umowy o pracę. Za świadczenie pracy „,na wyłączność” jednego pracodawcy, pracownik może domagać się wypłaty dodatkowego miesięcznego wynagrodzenia, nie wyższego jednak niż minimalne wynagrodzenie za pracę. Tak sformułowany przepis oznacza, że strony mogłyby przewidzieć niższe świadczenie, w gruncie rzeczy dowolne, ponieważ jego wartość minimalna nie została określona. Ponadto, należy

30 Wyrok TK z dnia 24.01.2001 r., SK 30/99, OTK 2001, nr 1, poz. 3, s. 129.

31 Por. R. Celeda, Kodeks pracy po nowelizacji. Obowiazki pracodawcy i pracownika, cz. II, Prawo Pracy 1996/8, s. 35-36.

32 Dz.U. z 1974, nr 24, poz. 141. 
dojść do wniosku, że pracownik nawet w czasie wolnym od pracy nie mógłby wykonywać jakichkolwiek czynności zarobkowych, np. realizować odpłatnie swojego hobby. Przepis zmierza w kierunku całkowitego zawłaszczenia pracy przez jeden podmiot, co zasadniczo sprzeciwia się zarówno wolności pracy, jak i swobodzie gospodarowania. Propozycja przepisu budzi uzasadnione wątpliwości w zakresie zgodności z art. 31 ust. 3 ustawy zasadniczej, który sprzeciwia się wprowadzaniu ograniczeń w zakresie korzystania z konstytucyjnych wolności i praw. Wprawdzie ustawodawca ma prawo wprowadzenia zakazów lub ograniczeń wolności pracy, ,jednak ingerencja ta musi być usprawiedliwiona koniecznością ochrony konstytucyjnych wartości, a przyjęte środki pozostawać w proporcji do zamierzonego celu"33. Propozycja Komisji w zakresie umowy o zakazie konkurencji nie spełnia tego warunku.

\section{Zakończenie}

Przedstawione powyżej propozycje Komisji Kodyfikacyjnej Prawa Pracy budzą uzasadnione wątpliwości w zakresie zgodności z konstytucyjną zasadą wolności pracy, wyrażoną w art. 65 ust. 1 ustawy zasadniczej. Kontrowersyjne są zwłaszcza regulacje ograniczające prawo wyboru podstawy zatrudnienia wyłącznie do stosunku pracy. Stanowią one zarazem rozwiązania zbyt dalece ingerujące w prawo umów, ograniczając jednocześnie swobodę prowadzenia działalności gospodarczej. Również tzw. domniemanie istnienia stosunku pracy, polegające na przerzuceniu ciężaru dowodu na pracodawcę w zakresie udowodnienia braku jego kierownictwa, zdaje się być praktycznie niewykonalne. Różnica pomiędzy kierownictwem pracodawcy a kierownictwem zlecającego czynności na podstawie art. 430 k.c. nie zawsze jest możliwa do wykazania. W doktrynie prawa pracy od dawna pisze się o tzw. podporządkowaniu autonomicznym, co ma podkreślić niezależność pracownika od pracodawcy. W obecnych warunkach świadczenia pracy zacierają się granice pomiędzy umową o pracę a umową o świadczenie usług.

Krytycznie trzeba ocenić również propozycje nowych umów o pracę, których wspólną cechą jest brak pewności zatrudnienia. Komisja wybrała rozwiązanie budzące wiele wątpliwości w systemie prawa pracy, tworząc sytuację, w której zatrudniony na podstawie nietypowych umów o pracę w zamian za przyznanie niektórych uprawnień socjalnych zarazem rezygnowałby z ochrony stosunku pracy.

33 Tak A. Śledzińska-Simon, op. cit., s. 22. 
Nieprzychylnie odnoszę się do propozycji umowy o zakazie konkurencji w czasie trwania stosunku pracy. Stwarza ona sytuację krańcowej lojalności wobec jednego pracodawcy, przyznając pracownikowi prawo do bliżej niesprecyzowanego wynagrodzenia gwarancyjnego, które nie może przekraczać stawki płacy minimalnej. Ograniczenie dotyczące samozatrudnienia lub świadczenia pracy na rzecz innego podmiotu nieprowadzącego działalności konkurencyjnej wobec pracodawcy stanowi oczywistą sprzeczność z konstytucyjną zasadą wolności pracy.

\section{Bibliografia}

\section{Akty prawne}

Konstytucja Rzeczypospolitej Polskiej z dnia 2 kwietnia 1997 r. (Dz.U., nr 78, poz. 483 ze zm.). Rozporządzenie Prezesa Rady Ministrów z dnia 20 czerwca 2002 r. w sprawie „Zasad techniki prawodawczej” (Dz.U. z 2002 r., nr 100, poz. 908).

Rozporządzenie Rady Ministrów z dnia 9 sierpnia 2016 r. w sprawie Komisji Kodyfikacyjnej Prawa Pracy (Dz.U. z 30.08.2016 r., poz. 1366).

Ustawa z dnia 26 czerwca 1974 r. Kodeks pracy (Dz.U. z 1974 r., nr 24, poz. 141 ze zm.).

Ustawa z dnia 10 października 2002 r. o minimalnym wynagrodzeniu za pracę (t.j. Dz.U. z 2018 r., poz. 2177).

Ustawa z dnia 5 lipca 2018 r. o zmianie ustawy o związkach zawodowych oraz niektórych innych ustaw (Dz.U. z 22 sierpnia 2018 r., poz. 1608).

\section{Opracowania}

Boruta Irena, Pracować nad lepsza przyszłością. W sprawie raportu Światowej Komisji ds. przyszłości pracy (MOP), PiZS 2019/3.

Celeda Ryszard, Kodeks pracy po nowelizacji. Obowiąki pracodawcy i pracownika, cz. II, Prawo Pracy 1996/8.

Florczak Izabela, Status prawny osób świadczacych prace w ramach umownego zatrudnienia nietypowego, Wydawnictwo Uniwersytetu Łódzkiego, Łódź 2017.

Gladoch Monika, Prawo wyboru podstawy zatrudnienia w kontekście zasady swobody prowadzenia działalności gospodarczej, PiZS 2018/3.

Liszcz Teresa, Aksjologiczne podstawy prawa pracy, w: Krzysztof W. Baran (red.), System prawa pracy, Tom I: Część ogólna, Wolters Kluwer Polska, Warszawa 2017.

Markiewicz-Stanny Joanna, Wolność pracy ludzkiej. Studium z zakresu praw człowieka, Oficyna Wydawnicza Uniwersytetu Zielonogórskiego, Zielona Góra 2015.

Musiała Anna, Zatrudnienie niepracownicze, Difin, Warszawa 2011.

Patulski Andrzej, Wolność pracy - próba ujęcia wielopłaszczyznowego, Wydawnictwa Uniwersytetu Warszawskiego, Warszawa 1992.

Sobczyk Arkadiusz, Podmiotowość pracy i towarowość ustug, Wolters Kluwer S.A., Kraków 2018.

Śledzińska-Simon Anna, Wolność pracy, w: Mariusz Jabłoński (red.), Realizacja i ochrona konstytucyjnych wolności i praw jednostki w polskim porzadku prawnym, E-Wydawnictwo. Prawnicza i Ekonomiczna Biblioteka Cyfrowa, Wrocław 2014. 
Świątkowski Andrzej M., Prawo wyboru podstawy zatrudnienia, Studia Iuridica Lublinensia 2015/XXIV/3, s. 237-246.

Tomaszewska Monika, Zasada wolności pracy w europejskim prawie wspólnotowym, Ars boni et aequi, Poznań 2003.

Monika GŁADOCH

\title{
THE EVALUATION OF SELECTED REGULATIONS OF THE DRAFT OF THE LABOUR CODE PROVIDED BY THE LABOUR LAW CODIFICATION COMMITTEE (2016-2018) IN THE CONTEXT OF THE PRINCIPLE OF FREEDOM OF CONTRACT
}

\begin{abstract}
Background: The article concerns some aspects of the work of the Codification Committee in 2016-2018 related to freedom of work. The Author, who was a participant in this work, presents selected solutions contained in the draft of Labour Code. She draws attention to their noncompliance with the principle of freedom of work and criticizes the proposal to limit the choice of employment base, as well as new the employment contracts. She draws attention to the practical risks associated with their entry into force.

Research purpose: To analyze selected regulations contained in the draft of the Labour Code from the point of view of the principle of freedom of work. To assess their impact on labour law and the labour market. To compare these regulations with applicable and previous Labour Code regulations, as well as with solutions in force in Western European countries.

Methods: Analytical, historical, comparative.

Conclusions: The Author negatively assesses some of the proposals contained in the draft of the Labour Code due to violation of the principle of freedom of work.

Keywords: the Labour Law Codification Committee, Labour Code, freedom of work, non-competition contract, employment contract.
\end{abstract}

